\title{
Of banks, books, and balls: The Lobo Library credit card
}

\author{
By Lynn Trojahn and Linda $K$. Lewis
}

\section{An affinity card benefits UNM libraries and atbletics}

$\mathbf{F}$ our hundred years ago, John Locke said, "A sound mind in a sound body is a short but full description of a happy state in this world." The mind/body connection led to a happy state at the University of New Mexico (UNM) as well, when academics and athletics joined forces to benefit "Lobos" both off and on the playing field.

The fruitful partnership between Lobo athletics and the Lobo libraries began in July 1994. The inception of the Intel Scores for Scholars Program, in which the Intel Corporation contributes acquisitions money to the libraries for every home score in football and basketball, inspired an abundance of joint programs. The most notable collaboration is UNM's basketball coach, Dave Bliss, serving as chair of the UNM Library Annual Fund Campaign.

It didn't take a rocket scientist to realize that libraries and athletics can help each other, as they have at other universities. The

The UNM Hbraries support
every academic unit on
compus; the fibraries
support everyone.
market.

\section{The nuts and bolts}

First State Bank is the only locally owned and managed major bank system in New Mexico. It is a bank that stresses New Mexico first, and its employees are actively involved in the community. One First State Bank employee who is a member of the board of the Lobo Club (the community support organization for UNM athletics), presented the idea of an "affinity card" to help support athletics. It was a project that would also help First State Bank launch its first Visa/MasterCard in the New Mexico

Banks began developing affinity credit cards in the 1980s as a way of expanding their customer base. These credit cards are targeted to a specific group of people who share common interests. Affinity cards supporting charitable organizations, universities, societies, and even fans of country music have been issued in recent years. The groups may receive part of the card's membership fee and a percent of the amounts charged. The bank benefits by gaining new customers. Although some universities and their alumni groups have had affinity cards for several years, UNM may be the UNM libraries provide academic credibility to athletics, and Lobo athletics provide visibility and excitement to the libraries. This very new relationship at UNM, and the ensuing dollars and respect garnered by both entities, led to one of UNM's most important strategic partnerships: the First State Bank Lobo Library Credit Card. first library with its own card.

From the beginning, First State Bank intended that the card support academics as well as athletics. Its first thought was that the card could help provide scholarship money. When athletics brought up the idea of the libraries, the program began to have focus. James $\mathrm{E}$. Warden, a senior vice-president at First State, said, 
"The intention from day one was to bring academics into the mix. Earmarking money to the libraries really made sense. Scholarships help many students in New Mexico, but the UNM libraries support every academic unit on campus; the libraries support everyone."

At this point, athletics brought the idea to the university's Purchasing Department. Given that many banks support athletics, it was important to give all local institutions the chance to bid on this proposal. At the same time, Mike Alden, the associate director of Lobo athletics, and Jack Harney,

the director of the

Lobo Club, ap proached the library as partners for the affinity card. Why would athletics ask the libraries to be partners and actually split some of this hardearned money? The decision was actually a smart one; it increased the the card, and so for all parties.

\section{An affinity for the libraries}

In the last few years, the UNM libraries have developed an active fundraising program. There have been traditional approaches, such as telephone and mail campaigns to alumni, friends groups, and parents of students, as well as appeals to corporate donors. One of the more unusual efforts has been a Valentine's Day Sock Hop, complete with music, cars, and costumes from the 1950s. The libraries have been willing to try new approaches to fundraising, and have sought new partners to support the library programs. This innovative attitude led to the willingness to join the affinity card program.

After the bid process was complete, First State Bank came out the winner. It was the bank willing to put in the marketing money and man-hours to have the credit card be successful. On the UNM side, major administrative support was needed. After the dean of the libraries approved the library involvement, proponents of the plan needed the approval of UNM's provost, the chief academic officer of the institution.

Then-UNM provost Mary Sue Coleman (who is now president of the University of Iowa) was a great library supporter. She realized that for the libraries to succeed in their fundraising, risk and entrepreneurship were of paramount importance. She not only approved the libraries' partnering with athletics and First State Bank, she accepted the idea that an application form for the credit card be sent to all faculty and staff of the university. If the credit card had benefited only athletics, the offer would never have gone to all UNM employees. With the broader scope of the libraries and academics, the credit card appealed to a much larger audience. Warden knew that bringing in the libraries "brought in a structured and growing market or donor base. So many people had an affinity to the libraries that the libraries would attract affinity card prospects." The solicitation for the card invited potential credit card applicants to choose between their $\$ 25$ initiation fee going to the libraries or to athletics; the majority of UNM employees chose the libraries. In addition, $1 \%$ of the debt charged to the cards each month is divided between the libraries and athletics, helping both groups.

In other words, by involving the libraries, athletics picked up hundreds of UNM employees who have an affiliation with the libraries-which is why they applied for the credit card-who are now, through their monthly debt, giving to both the libraries and athletics.

The credit card design also contributes to an affinity with the libraries. A picture of Zimmerman Library, UNM's flagship library and a premiere example of New Mexico Pueblo style architecture, was painted by a local advertising agency to adorn the credit card. The image of the most recognizable building on campus makes this beautiful credit card a piece of art that cardholders are proud to use. 


\section{The sweet smell of success}

First State Bank divided the mailing list of potential applicants into four groups: Lobo Club members, season ticket holders for athletic events, library friends group members, and UNM employees. Almost 20,000 people were approached, with the solicitation targeted to the specific group. For example, Lobo Club members were asked to apply by the president of the Lobo Club, and UNM employees by the dean of the libraries. First State Bank paicl for all graphics, print materials, advertising, and mailing. It also contributed each applicant's $\$ 25$ initiation fee to the fund.

Between January 1996 and Octolyer 1996, the following occurred:

- 1,000 individuals, or $60 \%$ of those solicited, applied and were preapproved for Lobo Library Credit Cards. This is a phenomenal result for a project that depended solely on direct mail. Even with telemarketing, which was not a component of this campaign, affinity cards usually produce only a two to three percent response rate.

- Of those 1,000 individuals, $60 \%$ asked that their initiation fee go to the libraries, for a total of $\$ 15,000$.

- After ten months of use, there is an aver-

\section{F.W. Lancaster \& Beth Sandore TECHNOLOGY AND}

\section{MANAgement In LIBRARY}

\section{AND}

\section{INFORMATION SERVICES}

THE INTEGRATION OF TECHNOLOGY INTO LIBRARY OPERATIONS HAS GREATLY CHANGED THE MANNER IN WHICH TASKS ARE ACCOMPLISHED. THIS NEW TITLE FOCUSES ON THE MANAGEMENT OF TECHNOLOGY RATHER THAN THE TECHNOLOGY ITSELF: IT IS THE MANNER IN WHICH NEW TOOLS ARE USED THAT WILL MAKE THE DIFFERENCE IN CONTEMPORARY LIBRARIES

\section{ISBN 087845-099-8; \$39.50+ SHIPPING}

ORDERS MUST BE PREPAID TO THE 'UNIVERSITY OF ILLINOIS.' MAJOR CREDIT CARDS ACCEPTED

GRADUATE SCHOOL OF LIBRARY AND INFORMATION SCIENCE, UNIVERSITY OF ILLINOIS, 501 E. DANIEL StReet, Champaion, IL 61820

(2) 7 ) 333-1359 TELEPHONE

(21 7) 244-7329 FAX

PUBOFF@ALEXIA.LIS.UIUC.EDU age balance of debt from these cards of $\$ 593,329$. Therefore, each month $\$ 5,930$ will be split between the libraries and athietics. That amount will probably continue to increase as cardholders continue to use their cards.

- The libraries received $\$ 15,000$ plus a potential $\$ 2,500$ each month for a projected total contribution of $\$ 40,000$ for the first year of this program.

\section{A strategic partnership works}

For an affinity card, these results are extraordinary. Why has this strategic partnership worked so well?

- First State Bank is a local bank that is willing to try new ideas and to spend money to have the product be exceptional. Of course, First State Bank has also benefited by receiving positive publicity and goodwill for this project, as well as acquiring new customers.

- The program partners two campus institutions, each of which has a loyal base of support both on and off campus.

- The Lobo Library credit card is not competing with the UNM Alumni Association affinity carcls or other funding projects on campus. There is some overlap between the alumni and the audience targeted by this card, but it is not enough to be significant.

- There is a great working relationship among the bank, athletics, and the libraries that nourishes the ability to work through issues and problems, creating a situation in which all parties win.

Jack Harney, director of the Lobo Club, continues to be excited about the partnership. There are a few detractors of the program, but Harney reminds the naysayers that "without the libraries' partnership we would not have the ongoing success that this credit card provides on a monthly basis. The libraries brought in hundreds of applications and a loyal base of support-it's a match made in heaven."

This type of project is not for the faint of heart. It has involved delicate maneuvering among all parties concerned. The project demanded that administrators on campus take risks-a notion that can be completely antithetical to bureaucracies and the political climate at a university. We had the right players, committed to the right goals, who were willing to go out on a limb to make a difference. The First State Bank Lobo Library credit card is an unequivocal success. 


\section{Give}

your clients

their own

information

\section{system.}

\section{SwetScan}

a complete, easy-to-use table of contents system:

- 14,000 journals

- powerful web-based searching

- frequent updates

- complete document delivery service from CISTI

Get the best international coverage with $65 \% \mathrm{sci} /$ tech and medical titles. Searching

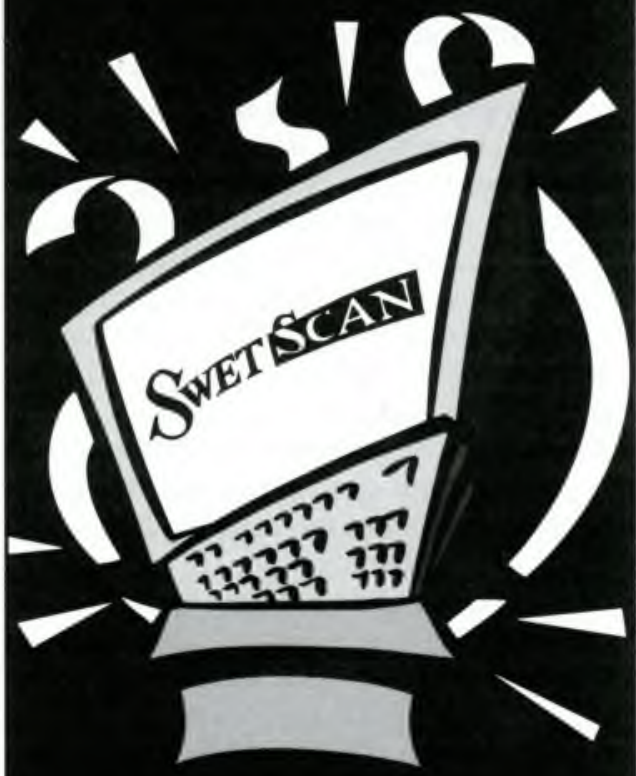
and document ordering can be customized to your needs.

For a free one-month trial call 1-800-668-1222 or e-mail: cisti.swetscan@nrc.ca

SwetScan - the smart way to meet the growing demands of your clients.

A service from CISTI - Canada Institute for Scientific and Technical Information.

MC.CNRC

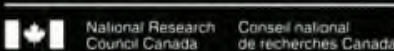

Canadä 